\title{
The role of platelet microvesicles in intercellular communication.
}

Leonard C. Edelstein

Thomas Jefferson University

Follow this and additional works at: https://jdc.jefferson.edu/cardeza_foundation

Part of the Hematology Commons

Let us know how access to this document benefits you

\section{Recommended Citation}

Edelstein, Leonard C., "The role of platelet microvesicles in intercellular communication." (2017).

Cardeza Foundation for Hematologic Research. Paper 42.

https://jdc.jefferson.edu/cardeza_foundation/42

This Article is brought to you for free and open access by the Jefferson Digital Commons. The Jefferson Digital Commons is a service of Thomas Jefferson University's Center for Teaching and Learning (CTL). The Commons is a showcase for Jefferson books and journals, peer-reviewed scholarly publications, unique historical collections from the University archives, and teaching tools. The Jefferson Digital Commons allows researchers and interested readers anywhere in the world to learn about and keep up to date with Jefferson scholarship. This article has been accepted for inclusion in Cardeza Foundation for Hematologic Research by an authorized administrator of the Jefferson Digital Commons. For more information, please contact: JeffersonDigitalCommons@jefferson.edu. 
The role of platelet microvesicles in intercellular communication

Leonard C. Edelstein*

Cardeza Foundation for Hematologic Research, Department of Medicine, Thomas Jefferson University, Philadelphia, PA

${ }^{*}$ Corresponding Author

leonard.edelstein@jefferson.edu

1020 Locust St., Suite 394

Philadelphia PA, 19107

215-955-1797 


\begin{abstract}
In recent years there has been exponential growth in the interest in microvesicles, which is reflected by the number of publications. Initially referred to as "platelet dust" by Peter Wolf in 1967, platelet microvesicles (PMV) are now recognized as important mediators of intercellular communication. There are examples of PMV exerting physiological effects on almost all hematological and vascular cell types, including monocytes, macrophages, neutrophils, T-cells, endothelium cells, and smooth muscle cells. PMV can exert these effects by multiple methods: extracellular signaling through receptors, transfer of surface molecules, and delivery of intracellular contents including miRNA. Recent work suggests a complex environment in which cellular contents are being shared muti-directionally between multiple cell types. This review will focus on the communicative properties of PMV.
\end{abstract}




\section{Introduction}

Extracellular vesicles (EVs) are membrane bound vesicles produced by almost every type of cell that resides in or contacts the blood. Many investigators have become interested in EVs for several reasons: (1) Their quantity increases in many pathological conditions [1]; (2) They participate directly in physiological processes such as thrombin generation [2]; and (3) they serve as mediators of intercellular communication, directly affecting the biology of target cells or delivering bioactive molecules. This review will focus on the role of platelet microvesicles (PMV), one of the most abundant circulating MV, in intercellular communication [3]. The review will cover advances in the understanding of how PMV interact with target cells in a variety of modes including lipid-mediated signaling, protein-mediated signaling, surface receptor transfer, cytosolic content transfer, and miRNA transfer. In addition, the mechanisms by which PMV are produced and taken up by target cells is briefly summarized.

\section{Production of platelet microvesicles}

Platelets produce PMV in response to a large number of stimuli. Complement protein C5b-9, bacterial lipopolysaccharide, cold storage, and influenza virus $\mathrm{H} 1 \mathrm{~N} 1$ all have been reported to generate PMV from exposed platelets [4]. PMV formation is closely connected to the formation of surface phosphatidylserine (PS) positive, procoagulant platelets. The connection between PS exposure and PMV formation was first observed in response to platelet stimulation with thrombin or collagen [5]. Since that report, many investigators have reported that dual stimulation with collagen and thrombin, or a single agonist combined with shear stress is required for maximal PMV production [6; 7]. While shear alone does not result in PMV generation, shear plus von Willebrand Factor (VWF) does [8]. The requirement for vWF for shear-generated PMV is supported by evidence that antibodies that block the vWF receptor, GIPba, suppress PMV production [9]. PS exposure and PMV production have also been linked to elevated cytosolic $\mathrm{Ca}^{2+}$ levels and to the activation of the $\mathrm{Ca}^{2+}$ protease, calpain $[6 ; 7 ; 10]$. PS is normally located on the inner leaflet of the cellular membrane and exposure requires the action of "flippases" to transfer the PS to the outer membrane. PS exposure leads to assembly of prothrombinase complexes on the surface of platelets. A defect in platelet PS exposure leads to the bleeding disorder and defective PMV release in Scott syndrome patients. TMEM16F, which is mutated in Scott syndrome patients, has been identified as the $\mathrm{Ca}^{2+-}$ dependent flippase responsible for PS-exposure and PMV release [11]. Being that increased shear, as found at thrombosis sites, plays a role in PMV formation and that PS+ PMV can generate thrombin, it is a matter of debate whether PMV are a cause or result of thrombosis. Perhaps PMV serve as a mechanism by which a thrombus is propagated and sustained. In addition to the above processes, proteasome function, cytoskeletal rearrangement, protein tyrosine phosphatase activity and outside-in signaling through the platelet fibrin receptor have been implicated in PMV formation [4].

\section{Content of platelet microvesicles}

MV cellular origin is determined by surface markers inherited from the parental cell. While platelet surface proteins such as CD41, CD42, and CD61 are typically used identify PMV, these markers are present on the platelet precursor, the megakaryocyte, which also produces MVs [8; 12]. Flaumenhaft and colleagues reported that a majority of MVs generated from platelets expressed CD62P and contained cleaved filamin A. However most plasma CD41+ MVs did not expressed CD62P and contained both intact and cleaved filamin A. These data suggest that a significant portion of circulating CD41+ MVs actually originate from megakaryocytes and not platelets [12].

PMV also contain a wide array of molecules including growth factors, coagulation factors, enzymes, adhesion molecules, chemokines, cytokines, complement proteins, apoptosis regulators, bioactive lipids, and miRNAs [1; 13]. PMV are more enriched in PS and P-selectin than the parental platelet, suggesting either an active process to select content or the occurence of MV budding in specific regions of the platelet membrane that are enriched for such factors [14]. There is evidence that under 
shear stress, platelets form flow induced protrusions (FLIPRs) from which PMV arise, supporting the hypothesis that PMV arise from specific regions of the platelet membrane [15]. PMV content can differ depending on the stimulus which generated them. A recent proteomic analysis of PMV identified 3383 proteins. The levels of these proteins were different depending on the agonist that produced the PMV [16]. In addition, PS content was found to be higher in $\mathrm{Ca}^{2+}$ ionophore A23187 induced PMV compared to thrombin-stimulated PMV, indicating stimulus-specific membrane composition [17].

\section{Platelet microvesicles as intercellular communication mediators}

PMV can interact with other cells in multiple ways: both proteins and bioactive lipids on the surface of MV have been implicated in triggering receptors on target cells. Fusion of MV and target cells can lead to the transfer of membrane integral proteins, adding new functions to the larger cell. Internalization and unpacking results in the delivery of cytosolic enzymes and miRNAs. In addition, there has been several reports of MV effects on target cells in which the mode of interaction in not known. Table 1 summarizes the literature of interactions between PMV and target cells.

\section{Lipid-mediated signaling}

One of the first descriptions of a mechanism by which PMV activate cells was by Garrett FitzGerald et al. They reported that arachidonic acid (AA) from PMV induced platelet aggregation and found the PMV AA was metabolized by the platelet into thromboxane $A_{2}\left(T X A_{2}\right)$. PMV AA also induced COX-1 expression and prostacyclin $\mathrm{PGI}_{2}$ production [18]. The following year they reported that PMV AA stimulated an increase in intracellular adhesion molecule-1 (ICAM-1) expression in human umbilical vein endothelial cells (HUVECs). This increase lead to enhanced monocyte:endothelial interactions. PMV AA also caused an increase in lymphocyte function-associated antigen-1 (LFA-1) and macrophage antigen-1 (Mac-1) in monocytes and the U-937 monocytic cell line. These changes in surface antigens were accompanied by enhancement of chemotaxis in U-937 cells [19]. The mechanism for these effects was later reported to be dependent on the Protein Kinase $C$ (PKC) and Mitogen Activated Protein Kinase (MAPK) pathways [20]. In contrast to this work, where AA is transferred from PMV to target cells and metabolized, Sandra Pfister reported that AA is transferred to PMV from rabbit pulmonary artery endothelial cells. The $A A$ was subsequently metabolized into $\mathrm{TXB}_{2}$ in the PMV. Differences in experimental approaches and endothelial subtypes may explain this disparity [21].

Kim et al. have reported that treatment of HUVECs with PMV resulted in protection from apoptosis, enhanced proliferation, and agiogenesis, as measured by tube formation assays. While heat treatment of the PMV prior to adding them to HUVECs had little result, charcoal treatment resulted in a significant reduction of these effects. As charcoal treatment removes nonpolar lipids, the authors reasoned that a lipid component of PMV was responsible for stimulation of HUVECs [22].

\section{Extracellular protein mediated signaling}

There have been several studies that describe the PMV-induced effects on cells that are mediated by signaling proteins. While many of these proteins have been described as membraneassociated, others are not, and it is not clear if these proteins are secreted from the PMV or tethered to the PMV membrane. Brill et al. reported a pro-angiogentic effect of PMV treatment on rat arotic endothelial cells, which was dependent on the growth factors Vascular Endothelial Growth Factor (VEGF), basic Fibroblast Growth Factor (bFGF), and Platelet Derived Growth Factor (PDGF). PMV VEGF and PDGF also caused endothelial migration in a matrigel assay. This events were mediated via the Phosphoinositide 3-kinase (PI3K), Src, and Extracellular Regulated Kinase (ERK) pathways [23]. PMV have also been reported to enhance monocyte arrest on endothelial cells. This phenomenon was dependent on PMV deposition of the cytokine CCL5, also known as RANTES (Regulated on Activation, Normal T-cell Expressed and Secreted) onto activated endothelium [24]. 
Eric Boilard et al. reported that PMV in synovial fluid from patients with rheumatoid arthritis increased production of inflammatory cytokines in fibroblast-like synoviocytes in an IL-1 dependent manner [25]. PMV influences on inflammatory signaling was also recently discovered by Bei et al. They found that Staphylococcal superantigen-like protein 5-stimulated platelets produced PMV, which leads an increase interleukin $1 \beta(\mathrm{IL}-1 \beta)$, Tumor Necrosis Factor $\alpha$ (TNFa), and Monocyte Chemoattractant Protein1 (MCP-1) in monocytes. Neutralizing antibodies to CD40L caused a significant reduction in this phenomenon [26]. In contrast to the proinflammatory response described above, PMV may also have anti-inflammatory effects. Exposure to PMV resulted in a decrease in interferon y (IFNY), TNFa, and IL-6 secretion in CD4+ T-cells. PMV further caused an increase in Transforming Growth Factor $-\beta 1$ (TGF- $\beta 1$ ) production and differentiation of naïve CD4+ T-cells to Foxp3+ regulatory $\mathrm{T}$ cells. These effects were mediated by PMV TGF- $\beta 1$ [27].

\section{Receptor transfer}

Another mode in which PMV interface with target cells is membrane fusion. This results in the transfer of platelet surface proteins to the recipient cell, imparting new functions and immunological reactivity, potentially confounding identification and purification of cell types. Ratajczak et al. have reported a series of observations regarding the transfer of platelet surface proteins to various cell types. They first published their findings that human $\mathrm{CD}_{3} 4^{+}$and mouse Sca-1+ hematopoetic stem express interact with PMV via P-selectin glycoprotein ligand-1 (PSGL-1), which binds with P-selectin on activated platelets and PMV. This interaction resulted in the transfer of surface platelet proteins, such as CD41, CD61, CXCR4, and PAR-1. Electron microscopic analysis revealed a lack of intact platelets, suggesting a PMV-mediated effect. This transfer resulted in improved adhesion of these stem cells to endothelium and engraftment after transplantation in a murine model [28]. They next found that CXCR4, CD41, and Pselectin could be transferred to erythroblasts, myeloblasts, and monocytes [29]. Finally, they described how PMV delivery of CXCR4 to erythroblasts or UT-7 myeloid leukemia cells resulted in their ability to become infected by X4-trophic HIV [30].

PMV-mediated delivery of CXCR4 has been implicated in other processes as well. Transfer to angiogenic early outgrowth cells augmented pro-angiogenic properties including increased adhesion to the extracellular matrix and enhanced proliferation, migration and tube formation [31]. Finally, transfer of the platelet fibrinogen binding integrin, allbß3, by PMV enabled NF-KB signaling in response to GM-CSF (Granulocyte Macrophage Colony-Stimulating Factor) in neutrophils, potentially enhancing inflammation [32].

\section{PMV internalization}

Membrane fusion between PMV and cells can result in the contents of the PMV being deposited into the cytosol of the recipient cell. An early mechanistic description of MV:target cell fusion indicated that monocyte MV (MMV) bound to platelets via P-selectin:PSGL-1 interactions. Blocking PS with Annexin $\mathrm{V}$ did not prevent MMV:platelet association, but did inhibit membrane fusion, indicating a PSdependent mechanism [33]. More recently, MV derived from hypoxia-induced mesenchymal stem cells (MSC-MV) have been reported to be internalized by HUVECs in a PS-dependent manner [34].

Gas6 is a secreted protein that binds to externalized PS on cells, which then serves as a ligand for the tyrosine kinase receptors Tyro3, Axl, and Mer (TAMs). Happonen et al. have reported that PMV internalization by endothelial cells is mediated by interactions between Gas 6 and tyrosine receptor kinase AxI [35]. Other lipid mediators have been implicated in the MV internalization process. The catalytic activity of secreted phospholipase A2 group IIA (SPLA2-IIA) was found to be necessary for PMV internalization by neutrophils. SPLA2-IIA can use PMV membranes as a substrate to generate AA. AA can then be further converted into 12-hydroxyeicosatetraenoic acid (12-HETE) by 12-lipoxygenase (12- 
LOX), both of which were required for engulfment as well [36]. Further work remains to be done to better understand the regulation of MV uptake and to delineate potential differences between MV subtypes.

\section{Transfer of Protein}

Ray et al. reported that peroxisome proliferator-activated receptor y (PPARY), a ligand-activated transcription factor involved adipocyte differentiation, could be transferred to a THP-1 monocytic cell line [37]. Tang et al. demonstrated the PMV contain 12-LOX, which can be delivered to mast cells, where it leads to enhancement of lipoxin A4 (LXA4) production [38]. LXA4 is a negative regulator of inflammation, providing additional evidence that PMV can play both a positive and negative role in inflammatory responses. In an intriguing study, Boudreau et al. provided evidence that a subset of PMV contain functional mitochondria and that these mitochondria could be transferred to neutrophils [39]. The physiological consequence of this transfer in uncertain but it suggests the possibility of platelets being able to provide an "energy boost" to cells under conditions in which PMV are produced.

\section{Transfer of miRNA}

miRNAs are approximately 22 nucleotide regulatory RNAs expressed in multicellular organisms [40]. miRBase v21 (June 2014, http://www.mirbase.org/) lists 2588 mature human miRNAs while the GENCODE reference set (v22) derived from ENCODE data lists 4093 [41], although recent data provides strong evidence for more than twice that many [42]. MiRNAs regulate most $(>60 \%)$ mammalian protein coding genes [43]. Some miRNAs are expressed ubiquitously, but many are tissue and/or developmental stage specific [42; 44]. Guided by the miRNA sequence, the RNA-induced silencing complex (RISC) causes translational inhibition followed by mRNA degradation caused by Argonaute (Ago) nucleases [45]. The impact of miRNAs on gene expression is often to fine-tune and reduce noise in protein expression [46].

Because of the commonality of PMV elevation in cardiovascular disease, the interaction between PMV and the endothelium has been an area of high interest. In 2013, Gidlöf et al. reported finding miR22, miR-185, miR-320b, and miR-423-5p in the supernatant of activated platelets. These miRNAs were taken up by the endothelial cell line HMEC-1. This transfer was attenuated in the presence of brefeldin A, an inhibitor of vesicle formation. Delivery of miR-320b resulted in a downregulation of ICAM-1 expression in the HMEC-1 cells. While this report did not specify the extracellular vesicle responsible for the transfer, this was one of the first reports of vesicle-mediated platelet miRNA delivery [47]. A few months later, Patrick Provost et al. published their finding that PMV contain functional miR-223:Ago2 complexes. These PMV were internalized by HUVECs where they caused downregulation of miR-223 target mRNAs, FBXW7 and EFNA1 [48]. PMV-mediated delivery of miR-223 to HUVECs has also been reported to regulate the expression of the insulin-like growth factor 1 receptor (IGF1R). Downregulation of IGF1R sensitized the HUVECs to apoptosis caused by advanced glycosylation end products [49].

In addition to endothelial cells, PMV have also been reported to deliver miRNAs to macrophages. PMV-transferred miR-126-3p to macrophages resulted in lower expression levels of ATF3, ATP1B1, ATP9A, and RAl14. Of these, lower levels of ATF3 and ATP1B1 protein was confirmed. PMV treatment of macrophages also resulted decreased secretion of CCL4, Colony Stimulating Factor 1 (CSF1), TNFa, and enhanced phagocytic activity, although these effects appear to be miR-126-3p independent [50].

Elevated P?MV levels have also been reported in many cancers. PMV-transferred miR-223 to A549 human lung cancer cells resulted in lower levels of the tumor suppressor erythrocyte membrane protein band 4.1-like 3 (EPB41L3) mRNA and protein. Lower levels of EPB41L3 lead to enhanced tumor invasion in a transwell assay [51]. These results indicate the PMV-mediated miRNA delivery can affect gene expression in conditions beyond cardiovascular disease.

PMV signaling via unknown mediators 
Other physiological effects of PMV exposure to cells have been reported without the molecular mediator of the effect being identified. Exposure to PMV results in neutrophil activation as measured by CD11b expression and increased phagocytic activity. This activation required PMV P-selectin:neutrophil PSGL-1 interactions [52]. PMV also stimulated bovine coronary artery smooth muscle cells in a PDGFindependent manner [53]. Finally, exposure of THP-1 cells to PMV resulted in aggregation of those cells and production of tissue factor positive MV from them [54].

\section{Platelet microvesicle association with cardiovascular disease}

An increase in the concentration of PMV has been observed in almost all cardiovascular conditions, including acute coronary syndromes, arteriosclerosis obliterans, hypertension, type 2 diabetes, and other conditions [1]. MV, including PMV, elicit multiple responses from the endothelium. Endothelial cell (EC) exposure to PMV induces effects on proliferation, NO production, and angiogenesis [22]. Multiple reports have indicated that circulating plasma MVs from sick patients are inherently different from those of healthy subjects, inducing different responses in the cells to which they are exposed. Boulanger et al. demonstrated that MV from patients with myocardial infarction impaired endothelium-dependent relaxation, whereas MVs from healthy controls did not [55]. MV from metabolic syndrome patients elicited less NO production from ECs.[56] Different angiogenic effects were observed with MV from type 2 diabetic patients compared to controls.[57] Even within an individual, MV isolated by endarterectomy from atherosclerotic plaques were able to induce proliferation and angiogenesis in EC, while circulating MV were not [58]. These data indicate that not only do PMV increase in quantity in pathological conditions, but their effects on external cells are altered. This is perhaps due to changes in the MV content modifying the signals they relay.

\section{Conclusion}

Recent discoveries of the properties of EV reveal a world in which cellular content, including genetic material, is constantly being exchanged between multiple cell types, both healthy and pathological. This review has focused on the role of PMV, but there is evidence that MV and exosomes from many cell types can signal and transfer their content extracellularly. Additionally, it has been reported that platelets can adsorb RNA from the milieu of tumors, leading to the concept of the platelet as sentinel for pathological conditions [59]. With the uncovering of this new world of intercellular communication, analysis of platelet RNA and protein content now must be thought of in context of where it originated from and where it may be transferred to. Additionally, the novel roles of platelets and platelet RNA in multiple biological processes and pathological conditions may be uncovered, leading to new biomarkers and new therapeutic targets. 
Table 1. Summary of reported PMV mediated communication events.

\begin{tabular}{|c|c|c|c|c|}
\hline & Target Cell & $\begin{array}{l}\text { MV } \\
\text { molecule(s) }\end{array}$ & Physiological Consequence & Reference \\
\hline \multicolumn{5}{|l|}{$\begin{array}{l}\text { Lipid Mediated } \\
\text { Signaling }\end{array}$} \\
\hline & Platelets & $\begin{array}{l}\text { Arachadonic } \\
\text { Acid }\end{array}$ & $\begin{array}{ll}\text { - } & \text { Aggregation } \\
\text { - } & \text { Thromboxane Generation } \\
\text { - } & \text { Increase in COX }-2^{1} \text { expression }\end{array}$ & [18] \\
\hline & HUVEC $^{2}$ & $\begin{array}{l}\text { Arachadonic } \\
\text { Acid }\end{array}$ & $\begin{array}{ll}\text { - } & \text { Increased surface ICAM-133 } \\
\text { expression } \\
\text { - Increased monocyte:HUVEC } \\
\text { adhesion }\end{array}$ & [19] \\
\hline & $\begin{array}{l}\text { U-937 macrophage } \\
\text { cell line }\end{array}$ & $\begin{array}{l}\text { Arachadonic } \\
\text { Acid }\end{array}$ & $\begin{array}{ll}\text { - } & \text { Increased Mac- } 1^{4} \text { and } \text { ITGAL }^{5} \\
& \text { expression } \\
\text { - } & \text { Increased Chemotaxis } \\
\end{array}$ & [19] \\
\hline & HUVEC & $\begin{array}{l}\text { Activated } \\
\text { charcoal } \\
\text { sensitive } \\
\text { factor }\end{array}$ & $\begin{array}{ll}\text { - } & \text { Enhanced proliferation } \\
\text { - } & \text { Enhanced survival } \\
\text { - } & \text { Enhanced migration } \\
\text { - } & \text { Enhanced tube formation }\end{array}$ & {$[22]$} \\
\hline & $\begin{array}{l}\text { Rabbit pulmonary } \\
\text { endothelial cells }\end{array}$ & COX-2 & $\begin{array}{l}\text { - Endothelial arachidonic acid is } \\
\text { transferred to the MV where it } \\
\text { produces } \mathrm{TXB}_{2}{ }^{6}\end{array}$ & {$[21]$} \\
\hline \multirow{6}{*}{$\begin{array}{l}\text { Protein Mediated } \\
\text { Signaling }\end{array}$} & & & $\bullet$ & \\
\hline & $\begin{array}{l}\text { Rat aortic } \\
\text { endothelial cells }\end{array}$ & $\begin{array}{l}\text { VEGF }{ }^{7}, \text { bFGF }^{8}, \\
\text { PDGF }^{9}\end{array}$ & - $\quad$ Enhanced Angiogenesis & {$[23]$} \\
\hline & $\begin{array}{l}\text { Activated } \\
\text { Endothelium }\end{array}$ & RANTES $^{10}$ & $\begin{array}{ll}\text { - } & \text { Enhanced monocyte arrest } \\
\text { - } & \text { Interaction required P-selectin, } \\
\text { GPIb, GPIIb/IIIa }{ }^{11} \text {, and JAM-A }{ }^{12}\end{array}$ & {$[24]$} \\
\hline & $\begin{array}{l}\text { Fibroblast-like } \\
\text { Synoviocytes }\end{array}$ & $\mathrm{IL}-1^{13}$ & $\begin{array}{l}\text { - Increased IL-6 and IL-8 } \\
\text { production }\end{array}$ & {$[25]$} \\
\hline & $\begin{array}{l}\text { Activated } \mathrm{CD}^{+} \mathrm{T} \\
\text { cells }\end{array}$ & TGF- $\beta 1^{14}$ & $\begin{array}{ll}\text { - } & \text { Decreased release of IFN }{ }^{15} \\
& \mathrm{TNF}^{16}, \text { and IL-6 } \\
\text { - } & \text { Increased production of TGF- } \beta 1 \\
\text { - } & \text { Increased } \mathrm{CD} 25^{\text {high }} \text { Foxp }^{+} \text {Tregs } \\
\end{array}$ & {$[27]$} \\
\hline & Monocytes & $\mathrm{CD}_{40 \mathrm{~L}^{17}}$ & $\begin{array}{l}\text { - Increase in inflammatory signals } \\
\left(\mathrm{IL}-1 \beta, \mathrm{TNF} \alpha, \mathrm{MCP}-1^{18}\right.\end{array}$ & [26] \\
\hline \multirow[t]{5}{*}{ Receptor Transfer } & & & $\bullet$ & \\
\hline & $\begin{array}{l}\text { - Human CD34+ } \\
\text { HSC } \\
\text { - Murine Sca- } 1^{+20}\end{array}$ & CD41 & $\begin{array}{l}\text { - Improved adherence to } \\
\text { endothelium } \\
\text { - } \quad \text { Improved engraftment }\end{array}$ & {$[28]$} \\
\hline & $\begin{array}{l}\text { - Erythroblasts } \\
\text { - Myeloblasts } \\
\text { - Monocytes }\end{array}$ & $\begin{array}{l}\text { CXCR4 } \\
\text { CD41 } \\
\text { CD62 }\end{array}$ & $\begin{array}{l}\text { - Increased adhesion, } \\
\text { proliferation, and survival } \\
\text { - } \text { Activate signaling }\end{array}$ & [29] \\
\hline & $\begin{array}{l}\text { - Erythroblasts } \\
\text { - UT-7 myeloid } \\
\text { leukemia cell line }\end{array}$ & $\begin{array}{l}\text { CD41 } \\
\text { CXCR4 }\end{array}$ & $\begin{array}{l}\text { Enables infection of previously } \\
\text { CXCR4 null cells by HIV } 22\end{array}$ & {$[30]$} \\
\hline & - Neutrophils & GPIIb/IIIa & - $\quad$ Enabled signaling to NF-KB ${ }^{23}$ in & {$[32]$} \\
\hline
\end{tabular}




\begin{tabular}{|c|c|c|c|c|}
\hline & & & response to ${\mathrm{GM}-\mathrm{CSF}^{24}}^{24}$ & \\
\hline & $\begin{array}{l}\text { - Angiogenic early } \\
\text { outgrowth cells }\end{array}$ & CXCR4 & $\begin{array}{l}\text { Increased adhesion to } \mathrm{ECM}^{25} \\
\text { - Enhanced proliferation, } \\
\text { migration, and tube formation }\end{array}$ & {$[31]$} \\
\hline \multicolumn{5}{|l|}{$\begin{array}{l}\text { Non-receptor } \\
\text { transfer }\end{array}$} \\
\hline & $\begin{array}{l}\text { THP-1 monocytic } \\
\text { cell line }\end{array}$ & $\begin{array}{l}\mathrm{PPARY}^{26} / \mathrm{RXR}^{27} \\
\text { complex }\end{array}$ & $\begin{array}{l}\text { - Capable of DNA binding and } \\
\text { affecting gene expression }\end{array}$ & [37] \\
\hline \multirow[t]{2}{*}{ I } & Mast cells & $\begin{array}{l}\text { 12- } \\
\text { lipoxygenase }\end{array}$ & - Enhanced lipoxin A4 production & {$[38]$} \\
\hline & Neutrophils & Mitochondria & - Unknown & [39] \\
\hline \multicolumn{5}{|l|}{ miRNA Transfer } \\
\hline & HUVEC & $\operatorname{miR}-223$ & $\begin{array}{l}\text { - Downregulation of } F B X W 7^{28} \text { and } \\
\text { EFNA1 } 1^{29} \text { RNA }\end{array}$ & [48] \\
\hline & $\begin{array}{l}\text { HMEC-1 human } \\
\text { microvascular } \\
\text { endothelial cell line }\end{array}$ & $\begin{array}{l}\text { miR-22 } \\
\text { miR-185 } \\
\text { miR-320b } \\
\text { miR-423-5p }\end{array}$ & - $\quad$ Reduction of ICAM-1 & {$[47]$} \\
\hline & HUVEC & miR-223 & $\begin{array}{ll}\text { - } & \text { Downregulation of IGF-1R } \\
\text { - } & \text { Apoptosis } \\
\end{array}$ & [49] \\
\hline & $\begin{array}{l}\text { A549 human lung } \\
\text { cancer cell line }\end{array}$ & miR-223 & $\begin{array}{ll}\text { - } & \text { Downregulation of EPB41L3 } \\
\text { - } & \text { Promotion of cell invasion } \\
\end{array}$ & {$[51]$} \\
\hline & Macrophages & miR-126-3p & $\begin{array}{l}\text { - Downregulation of } \mathrm{CCL} 4^{32} \text {, } \\
\mathrm{CSF}^{33}, \mathrm{TNF} \alpha \\
\text { - } \quad \text { Enhanced phagocytic capacity } \\
\end{array}$ & {$[50]$} \\
\hline \multicolumn{5}{|l|}{$\begin{array}{l}\text { Other/Unknown } \\
\text { effector }\end{array}$} \\
\hline & Neutrophils & & $\begin{array}{l}\text { - } \quad \text { Increase in neutrophil activation } \\
\text { as measured by CD11b } \\
\text { expression } \\
\text { - } \\
\text { - } \quad \text { Required P-selectin:PSGL-1 } \\
\text { interaction }\end{array}$ & {$[52]$} \\
\hline & $\begin{array}{l}\text { Bovine coronary } \\
\text { artery SMC } \text { SM }^{35}\end{array}$ & $\begin{array}{l}\text { PDGF } \\
\text { independent }\end{array}$ & - Stimulated proliferation & [53] \\
\hline & $\begin{array}{l}\text { THP-1 monocytic } \\
\text { cell line }\end{array}$ & & $\begin{array}{ll}\text { - } & \text { Aggregation of THP-1 cells } \\
\text { - } & \text { Production of TF } F^{+} \text {monocytic } \\
& \text { MVs }\end{array}$ & {$[54]$} \\
\hline
\end{tabular}

Legend: 1 - cyclooxygenase-2, 2 - Human Umbilical Vein Endothelial Cell, 3 - Intercellular Adhesion Molecule-1, 4 - Macrophage-1 Antigen, 5 -Integrin Subunit Alpha L, 6-Tromboxane B2, 7 - Vascular Endothelial Growth Factor, 8 -basic Fibroblast Growth Factor, 9 - Platelet Derived Growth Factor, 10 Regulated on Activation, Normal T cell Expressed and Secreted, 11-Glycoprotein, 12-Junctional Adhesion Molecule-A, 13 - Interleukin-1, 14 - Transforming Growth Factor - $\beta 1,15$ - Interferon $\gamma, 16$ Tumor Necrosis Factor $\alpha, 17$ - CD40 Ligand, 18 - Monocyte Chemoattractant Protein-1, 19 Hematopoietic Stem Cell, 20 - Stem Cell Antigen-1, 21 - Chemokine Receptor 4, 22 - Human Immunodeficiency Virus, 23 - Nuclear Factor - kB, 24 - Granulocyte Macrophage Colony-Stimulating 
Factor, 25 - Extracellular Matrix, 26 - Peroxisome proliferator-activated receptor, 27 - Rentinoid X Receptor, 28 - F-Box And WD Repeat Domain Containing 7, 29 - Ephrin A1, 30 - Insulin-Like Growth Factor 1 Receptor, 31 - Erythrocyte Membrane Protein Band 4.1 Like 3, 32 - C-C Motif Chemokine Ligand 4, 33 - Colony Stimulating Factor 1, 34 - P-Selectin Glycoprotein Ligand-1, 35 - Smooth Muscle Cells 


\section{Declaration of Interest}

The authors report no declarations of interest. This work was supported by the American Heart Association Grant 14GRNT20460004. 


\section{References}

1. Aatonen M, Gronholm M, Siljander PR. 2012. Platelet-derived microvesicles: Multitalented participants in intercellular communication. Semin Thromb Hemost. 38(1):102-113.

2. Owens AP, 3rd, Mackman N. 2011. Microparticles in hemostasis and thrombosis. Circ Res. 108(10):1284-1297.

3. Arraud N, Linares R, Tan S, Gounou C, Pasquet JM, Mornet S, Brisson AR. 2014. Extracellular vesicles from blood plasma: Determination of their morphology, size, phenotype and concentration. J Thromb Haemost. 12(5):614-627.

4. Boilard E, Duchez AC, Brisson A. 2015. The diversity of platelet microparticles. Curr Opin Hematol.

5. Fox JE, Austin CD, Reynolds CC, Steffen PK. 1991. Evidence that agonist-induced activation of calpain causes the shedding of procoagulant-containing microvesicles from the membrane of aggregating platelets. J Biol Chem. 266(20):13289-13295.

6. Heemskerk JW, Bevers EM, Lindhout T. 2002. Platelet activation and blood coagulation. Thromb Haemost. 88(2):186-193.

7. Morel O, Jesel L, Freyssinet JM, Toti F. 2011. Cellular mechanisms underlying the formation of circulating microparticles. Arterioscler Thromb Vasc Biol. 31(1):15-26.

8. Nomura S, Shimizu M. 2015. Clinical significance of procoagulant microparticles. Journal of intensive care. 3(1):2.

9. Pontiggia L, Steiner B, Ulrichts H, Deckmyn H, Forestier M, Beer JH. 2006. Platelet microparticle formation and thrombin generation under high shear are effectively suppressed by a monoclonal antibody against gpiba. Thrombosis and Haemostasis.

10. Delaney MK, Liu J, Kim K, Shen B, Stojanovic-Terpo A, Zheng Y, Cho J, Du X. 2014. Agonist-induced platelet procoagulant activity requires shear and a rac1-dependent signaling mechanism. Blood. 124(12):19571967.

11. Morel O, Morel N, Jesel L, Freyssinet JM, Toti F. 2011. Microparticles: A critical component in the nexus between inflammation, immunity, and thrombosis. Semin Immunopathol. 33(5):469-486.

12. Flaumenhaft R, Dilks JR, Richardson J, Alden E, Patel-Hett SR, Battinelli E, Klement GL, Sola-Visner M, Italiano JE, Jr. 2009. Megakaryocyte-derived microparticles: Direct visualization and distinction from platelet-derived microparticles. Blood. 113(5):1112-1121.

13. Hunter MP, Ismail N, Zhang X, Aguda BD, Lee EJ, Yu L, Xiao T, Schafer J, Lee ML, Schmittgen TD et al. 2008. Detection of microrna expression in human peripheral blood microvesicles. PLoS One. 3(11):e3694.

14. Sinauridze EI, Kireev DA, Popenko NY, Pichugin AV, Panteleev MA, Krymskaya OV, Ataullakhanov FI. 2007. Platelet microparticle membranes have 50 - to 100 -fold higher specific procoagulant activity than activated platelets. Thrombosis and Haemostasis.

15. Tersteeg C, Heijnen HF, Eckly A, Pasterkamp G, Urbanus RT, Maas C, Hoefer IE, Nieuwland R, Farndale RW, Gachet $C$ et al. 2014. Flow-induced protrusions (fliprs): A platelet-derived platform for the retrieval of microparticles by monocytes and neutrophils. Circ Res. 114(5):780-791.

16. Milioli M, Ibanez-Vea M, Sidoli S, Palmisano G, Careri M, Larsen MR. 2015. Quantitative proteomics analysis of platelet-derived microparticles reveals distinct protein signatures when stimulated by different physiological agonists. J Proteomics. 121:56-66.

17. Perez-Pujol S, Marker PH, Key NS. 2007. Platelet microparticles are heterogeneous and highly dependent on the activation mechanism: Studies using a new digital flow cytometer. Cytometry A. 71(1):38-45.

18. Barry OP, Pratico D, Lawson JA, FitzGerald GA. 1997. Transcellular activation of platelets and endothelial cells by bioactive lipids in platelet microparticles. J Clin Invest. 99(9):2118-2127.

19. Barry OP, Pratico D, Savani RC, FitzGerald GA. 1998. Modulation of monocyte-endothelial cell interactions by platelet microparticles. J Clin Invest. 102(1):136-144.

20. Barry OP, Kazanietz MG, Pratico D, FitzGerald GA. 1999. Arachidonic acid in platelet microparticles up-regulates cyclooxygenase-2-dependent prostaglandin formation via a protein kinase c/mitogen-activated protein kinase-dependent pathway. Journal of Biological Chemistry. 274(11):7545-7556.

21. Pfister SL. 2004. Role of platelet microparticles in the production of thromboxane by rabbit pulmonary artery. Hypertension. 43(2):428-433.

22. Kim HK, Song KS, Chung JH, Lee KR, Lee SN. 2004. Platelet microparticles induce angiogenesis in vitro. Br J Haematol. 124(3):376-384. 
23. Brill A, Dashevsky O, Rivo J, Gozal Y, Varon D. 2005. Platelet-derived microparticles induce angiogenesis and stimulate post-ischemic revascularization. Cardiovasc Res. 67(1):30-38.

24. Mause SF, von Hundelshausen P, Zernecke A, Koenen RR, Weber C. 2005. Platelet microparticles: A transcellular delivery system for rantes promoting monocyte recruitment on endothelium. Arterioscler Thromb Vasc Biol. 25(7):1512-1518.

25. Boilard E, Nigrovic PA, Larabee K, Watts GF, Coblyn JS, Weinblatt ME, Massarotti EM, Remold-O'Donnell E, Farndale RW, Ware J et al. 2010. Platelets amplify inflammation in arthritis via collagen-dependent microparticle production. Science. 327(5965):580-583.

26. Bei JJ, Liu C, Peng S, Liu CH, Zhao WB, Qu XL, Chen Q, Zhou Z, Yu ZP, Peter K et al. 2016. Staphylococcal ssI5induced platelet microparticles provoke proinflammatory responses via the cd40/traf6/nfkappab signalling pathway in monocytes. Thromb Haemost. 115(3):632-645.

27. Sadallah S, Amicarella F, Eken C, lezzi G, Schifferli JA. 2014. Ectosomes released by platelets induce differentiation of cd4+t cells into t regulatory cells. Thromb Haemost. 112(6):1219-1229.

28. Janowska-Wieczorek A, Majka M, Kijowski J, Baj-Krzyworzeka M, Reca R, Turner AR, Ratajczak J, Emerson SG, Kowalska MA, Ratajczak MZ. 2001. Platelet-derived microparticles bind to hematopoietic stem/progenitor cells and enhance their engraftment. Blood. 98(10):3143-3149.

29. Baj-Krzyworzeka M, Majka M, Pratico D, Ratajczak J, Vilaire G, Kijowski J, Reca R, Janowska-Wieczorek A, Ratajczak MZ. 2002. Platelet-derived microparticles stimulate proliferation, survival, adhesion, and chemotaxis of hematopoietic cells. Exp Hematol. 30(5):450-459.

30. Rozmyslowicz T, Majka M, Kijowski J, Murphy SL, Conover DO, Poncz M, Ratajczak J, Gaulton GN, Ratajczak MZ. 2003. Platelet- and megakaryocyte-derived microparticles transfer cxcr4 receptor to cxcr4-null cells and make them susceptible to infection by x4-hiv. AIDS. 17(1):33-42.

31. Mause SF, Ritzel E, Liehn EA, Hristov M, Bidzhekov K, Muller-Newen G, Soehnlein O, Weber C. 2010. Platelet microparticles enhance the vasoregenerative potential of angiogenic early outgrowth cells after vascular injury. Circulation. 122(5):495-506.

32. Salanova B, Choi M, Rolle S, Wellner M, Luft FC, Kettritz R. 2007. Beta2-integrins and acquired glycoprotein iib/iiia (gpiib/iiia) receptors cooperate in nf-kappab activation of human neutrophils. J Biol Chem. 282(38):27960-27969.

33. Del Conde I, Shrimpton CN, Thiagarajan P, Lopez JA. 2005. Tissue-factor-bearing microvesicles arise from lipid rafts and fuse with activated platelets to initiate coagulation. Blood. 106(5):1604-1611.

34. Wei X, Liu C, Wang H, Wang L, Xiao F, Guo Z, Zhang H. 2016. Surface phosphatidylserine is responsible for the internalization on microvesicles derived from hypoxia-induced human bone marrow mesenchymal stem cells into human endothelial cells. PLoS One. 11(1):e0147360.

35. Happonen KE, Tran S, Morgelin M, Prince R, Calzavarini S, Angelillo-Scherrer A, Dahlback B. 2016. The gas6-axl interaction mediates endothelial uptake of platelet microparticles. J Biol Chem.

36. Duchez AC, Boudreau LH, Naika GS, Bollinger J, Belleannee C, Cloutier N, Laffont B, Mendoza-Villarroel RE, Levesque T, Rollet-Labelle E et al. 2015. Platelet microparticles are internalized in neutrophils via the concerted activity of 12-lipoxygenase and secreted phospholipase a2-iia. Proc Natl Acad Sci U S A. 112(27):E3564-3573.

37. Ray DM, Spinelli SL, Pollock SJ, Murant TI, O'Brien JJ, Blumberg N, Francis CW, Taubman MB, Phipps RP. 2008. Peroxisome proliferator-activated receptor gamma and retinoid $\mathrm{x}$ receptor transcription factors are released from activated human platelets and shed in microparticles. Thromb Haemost. 99(1):86-95.

38. Tang K, Liu J, Yang Z, Zhang B, Zhang H, Huang C, Ma J, Shen GX, Ye D, Huang B. 2010. Microparticles mediate enzyme transfer from platelets to mast cells: A new pathway for lipoxin a4 biosynthesis. Biochem Biophys Res Commun. 400(3):432-436.

39. Boudreau LH, Duchez AC, Cloutier N, Soulet D, Martin N, Bollinger J, Pare A, Rousseau M, Naika GS, Levesque T et al. 2014. Platelets release mitochondria serving as substrate for bactericidal group iia-secreted phospholipase a2 to promote inflammation. Blood. 124(14):2173-2183.

40. Bartel DP. 2004. Micrornas: Genomics, biogenesis, mechanism, and function. Cell. 116(2):281-297.

41. Derrien T, Johnson R, Bussotti G, Tanzer A, Djebali S, Tilgner H, Guernec G, Martin D, Merkel A, Knowles DG et al. 2012. The gencode v7 catalog of human long noncoding rnas: Analysis of their gene structure, evolution, and expression. Genome Res. 22(9):1775-1789. 
42. Londin E, Loher P, Telonis AG, Quann K, Clark P, Jing Y, Hatzimichael E, Kirino Y, Honda S, Lally M et al. 2015. Analysis of 13 cell types reveals evidence for the expression of numerous novel primate- and tissuespecific micrornas. Proc Natl Acad Sci U S A.

43. Friedman RC, Farh KK, Burge CB, Bartel DP. 2009. Most mammalian mrnas are conserved targets of micrornas. Genome Res. 19(1):92-105.

44. Wienholds E, Kloosterman WP, Miska E, Alvarez-Saavedra E, Berezikov E, de Bruijn E, Horvitz HR, Kauppinen S, Plasterk RH. 2005. Microrna expression in zebrafish embryonic development. Science. 309(5732):310-311.

45. Bartel DP. 2009. Micrornas: Target recognition and regulatory functions. Cell. 136(2):215-233.

46. Schmiedel JM, Klemm SL, Zheng Y, Sahay A, Bluthgen N, Marks DS, van Oudenaarden A. 2015. Gene expression. Microrna control of protein expression noise. Science. 348(6230):128-132.

47. Gidlof O, van der Brug M, Ohman J, Gilje P, Olde B, Wahlestedt C, Erlinge D. 2013. Platelets activated during myocardial infarction release functional mirna, which can be taken up by endothelial cells and regulate icam1 expression. Blood. 121(19):3908-3917, S3901-3926.

48. Laffont B, Corduan A, Ple H, Duchez AC, Cloutier N, Boilard E, Provost P. 2013. Activated platelets can deliver mrna regulatory ago $2 *$ microrna complexes to endothelial cells via microparticles. Blood. 122(2):253-261.

49. Pan Y, Liang H, Liu H, Li D, Chen X, Li L, Zhang CY, Zen K. 2014. Platelet-secreted microrna-223 promotes endothelial cell apoptosis induced by advanced glycation end products via targeting the insulin-like growth factor 1 receptor. Journal of immunology. 192(1):437-446.

50. Laffont B, Corduan A, Rousseau M, Duchez AC, Lee CH, Boilard E, Provost P. 2016. Platelet microparticles reprogram macrophage gene expression and function. Thromb Haemost. 115(2):311-323.

51. Liang H, Yan X, Pan Y, Wang Y, Wang N, Li L, Liu Y, Chen X, Zhang CY, Gu H et al. 2015. Microrna-223 delivered by platelet-derived microvesicles promotes lung cancer cell invasion via targeting tumor suppressor epb4113. Mol Cancer. 14:58.

52. Jy W, Mao WW, Horstman L, Tao J, Ahn YS. 1995. Platelet microparticles bind, activate and aggregate neutrophils in vitro. Blood Cells Mol Dis. 21(3):217-231; discussion 231a.

53. Weber A, Koppen HO, Schror K. 2000. Platelet-derived microparticles stimulate coronary artery smooth muscle cell mitogenesis by a pdgf-independent mechanism. Thromb Res. 98(5):461-466.

54. Lin HC, Chang HW, Hsiao SH, Chou ML, Seghatchian J, Burnouf T. 2015. Platelet-derived microparticles trigger thp-1 monocytic cell aggregation and release of pro-coagulant tissue factor-expressing microparticles in vitro. Transfus Apher Sci. 53(2):246-252.

55. Boulanger CM, Scoazec A, Ebrahimian T, Henry P, Mathieu E, Tedgui A, Mallat Z. 2001. Circulating microparticles from patients with myocardial infarction cause endothelial dysfunction. Circulation. 104(22):2649-2652.

56. Agouni A, Lagrue-Lak-Hal AH, Ducluzeau PH, Mostefai HA, Draunet-Busson C, Leftheriotis G, Heymes C, Martinez MC, Andriantsitohaina R. 2008. Endothelial dysfunction caused by circulating microparticles from patients with metabolic syndrome. The American journal of pathology. 173(4):1210-1219.

57. Tsimerman G, Roguin A, Bachar A, Melamed E, Brenner B, Aharon A. 2011. Involvement of microparticles in diabetic vascular complications. Thromb Haemost. 106(2):310-321.

58. Leroyer AS, Rautou PE, Silvestre JS, Castier Y, Leseche G, Devue C, Duriez M, Brandes RP, Lutgens E, Tedgui A et al. 2008. Cd40 ligand+ microparticles from human atherosclerotic plaques stimulate endothelial proliferation and angiogenesis a potential mechanism for intraplaque neovascularization. J Am Coll Cardiol. 52(16):1302-1311.

59. Best MG, Sol N, Kooi I, Tannous J, Westerman BA, Rustenburg F, Schellen P, Verschueren H, Post E, Koster J et al. 2015. Rna-seq of tumor-educated platelets enables blood-based pan-cancer, multiclass, and molecular pathway cancer diagnostics. Cancer Cell. 